DOl 10.15826/Lurian.2020.1.1.11

УДК 159.928.235

\title{
Cognitive Neuroscience: Challenge of the Time
}

\author{
Sergey Yu. Kiselev \\ Svetlana V. Pavlova \\ Dauren A. Kasanov \\ Dmitry A. Tarasov \\ Georgy I. Borisov \\ Ural Federal University named after the first President of Russia B. N. Yeltsin, \\ Russia, Yekaterinburg

\section{Когнитивная нейронаука: \\ вызов времени}

\begin{abstract}
Сергей Ю. Киселев
Светлана В. Павлова

Даурен А. Касанов

Дмитрий А. Тарасов

Георгий И. Борисов

Уральский федеральный университет имени первого Президента России Б. Н. Ельцина, Россия, Екатеринбург

Corresponding author. E-mail:neurolab.ura@@gmail.com

Ural Federal University named after the first President of Russia B. N. Yeltsin in Yekaterinburg welcomed participants of the II International Forum "Cognitive Neuroscience - 2019" in November 2019. More than 300 Russian and foreign scientists took part in the Forum. A total 85 reports were presented.

This article is the final report about the Forum. The article presents relevant research directions that have become the subject of discussion by the Forum participants, a scope of Forum research areas and prospects for the development of cognitive neuroscience
\end{abstract} in general.

Keywords: International forum; cognitive neuroscience; scientific meeting; psychophysiology; clinical psychology; neuropsychology. 
В ноябре 2019 г. на базе Уральского федерального университета имени первого Президента России Б. Н. Ельцина в г. Екатеринбурге прошел II Международный форум по когнитивным нейронаукам “Cognitive Neuroscience - 2019”. В работе форума участвовали более 300 российских и зарубежных ученых. Всего было представлено 85 докладов.

В статье рассмотрены тематические направления работы форума. Представлены актуальные исследования, которые стали предметом обсуждения среди участников форума, проведен анализ работы разных направлений форума и сделаны выводы о дальнейших перспективах развития когнитивной нейронауки в целом.

Ключевые слова: международный форум; когнитивные нейронауки; научное мероприятие; психофизиология; клиническая психология; нейропсихология.

In November 2019, Ural Federal University named after the first President of Russia B. N. Yeltsin in Yekaterinburg hosted the II International Forum "Cognitive Neuroscience - 2019". The main goal of the Forum was the development of international scientific relations, consolidation of scientific resources for breakthrough fundamental research in the area of neuropsychology, clinical psychology, psychophysiology and other areas of cognitive neuroscience. Forum became a continuation of significant scientific events in the area of neuroscience that were held at Ural Federal University, including the Fifth International Luria Memorial Congress (2017), I International Forum "Cognitive neuroscience - 2018". More than 300 Russian and foreign scientists participated in the Forum.

The Forum program included plenary and breakout sessions, oral and poster presentations. There was also the young scientists section. The Forum covered 6 research areas: neurocognitive aspects of education; interdisciplinary research of the brain: age-related aspect; chronobiological aspects of psychological well-being and cognitive performance; philosophic and methodologic prospects of the cognitive researches; developmental psychophysiology; neurocognitive aspects of personality development in late adulthood. A total 85 reports were presented in the Forum.

Plenary session included the invited talks of world-recognized scientists in different areas of cognitive neuroscience.

Professor Sergey Malykh, member of the Russian Academy of Education, Head of the Laboratory of Developmental Psychogenetic of Psychological Institute at Russian Academy of Education (Moscow, Russia) gave the inspirational talk "Longitudinal researches of cognitive development". He showed the importance of longitudinal approach in the investigation of brain and cognitive development. In particular, he presented the results of a big longitudinal investigation of development in school-age children. The talk of professor Malykh covered issues related to human neurocognitive growth at different stages of development, mechanisms of maturation of cognitive functions in typically and atypically developing children, psychophysiological aspects of growth.

Professor Janna Glozman, Research Director of the Research Centre of Developmental Neuropsychology named after A. Luria, leading researcher of Neuropsycho- 
logical Laboratory (Moscow State University) presented the debatable talk "Cognitive neuroscience is not the same as neuropsychology: reasons and challenges". She showed a line between Neuropsychology and Cognitive neuroscience. Cognitive neuroscience was described as "an interdisciplinary approach that combines the efforts of cognitive psychology and neuroscience for study how sensory-perceptual and cognitive processes are implemented in the brain, including at the neural level". The representation of neuropsychology was presented from the point of view of the development of three historical stages. The first stage of neuropsychology is the research into brain organization of higher mental functions. The second stage is the analysis of the psychological structure of higher mental functions. The third stage is the analysis of the relationship between the patient with brain problems and the society in which he lives. Thus, the difference between cognitive neuroscience and neuropsychology is that the first branch of scientific knowledge explores the brain organization of cognitive processes, while the second is aimed at the study of cultural and social aspects of higher mental functions and their organization in the brain for the purpose of rehabilitation and adaptation to society.

Professor Dmitry Zaitsev, Faculty of Philosophy (Moscow State University), contributed to unraveling secret of investigation in the area of cognitive neuroscience in his talk "True Science of Argument and Reasoning: Logic or/and Cognitive Science?".

Professor Alexander Kaplan, Head of the laboratory of neurophysiology and neuro-computer interfaces (Moscow State University), presented the promising topic in modern cognitive neuroscience in his talk "Neurointerface technologies: achievements and prospects". A. Kaplan presented a survey of the current development of brain-computer interfaces $(\mathrm{BCI})$ - the systems that establish direct links between neural activity and hardware, bypassing nerves and muscles. As the examples of BCI, Russian systems "Exowrist-2" and "Neurochat" were submitted. "Exowrist-2" was created by the Institute of Higher Nervous Activity and Neurophysiology and Lomonosov Moscow State University. It is based on the fact that the post-stroke patient, representing the movement of the alloy limb, controls a device that mechanically helps him to perform a movement. "Neurochat" was developed by Lomonosov Moscow State University together with the companies "Neurochat" and "Neurotrend" supported by the branch association "Neuronet" and the national technology initiative (NTI) Foundation. "Nerochat" is a technology in which the patient focuses on a specific letter. The system recognizes his reaction and fixes the letter in the message due to the P300's evoked potential.

Professor Alexander Hramov, Head of neuroscience and cognitive technology laboratory (Innopolis University, Kazan), shared with participants of the Forum the results of research in his talk "The relationship of spatio-temporal structure of EEG with human personality during performing simple cognitive tests". Khramov talked about relationship between cognitive processes and personal characteristics. He used EEG method in this research. Participants were asked to undergo the "Schulte Tables" test while EEG being recorded. According to the EEG outcome, the participants were divided into 3 groups based on the results of brain neurons individual activity. In addition, the participants 
were also requested to complete a Cattell's 16 personality factors (16PF). It was shown that the neurons individual activity of these three groups was also different in such factors as cordiality, thinking, emotional stability and dominance. The results evaluating the respondents' mental abilities were also different.

Professor Vladimir Popov in his talk "Generation of deceptive actions by a robot to increase its own performance and safeness of interactions" raised the question of the possibility of artificial intelligence (robot) to generate deceptive actions in order to mislead another robot or person. A study was conducted with two robots, one of which could perform deceptive actions. Each of the robots had their own tasks which they could solve. It was shown that a robot that performed deceptive actions could mislead the second one, however, as a result of the study, a greater efficiency of both robots was achieved, and the frequency of collisions between two robots reduced while performing tasks.

Professor from Meiji Pharmaceutical University (Tokyo, Japan) Yoko Komada gave interesting talk in the practical-oriented topic on cognitive neuroscience "What is sleepiness? Association between subjective and objective". The results of the study showed a violation of neuropsychiatric function in sleep disorders such as sleep apnea and insufficient sleep syndrome, which in turn leads to an increased probability of road accidents.

Professor Claes von Hofsten, Uppsala University (Sweden), presented results of his world-recognized researches in the area of motor and cognitive development of infants in his talk "The early development of action skills".

At the end of plenary sessions, there was the panel discussion where the researchers in the area of cognitive neuroscience shared their thoughts about opportunities and risks in the modern cognitive neuroscience.

The section "Neurocognitive aspects of education" was devoted to using the neuroscience approach for investigation of different research topics in education. Researches presented and discussed the following topics: oculomotor indicators of emotional burnout syndrome (Lomonosov Moscow state University); professional evaluation in the solution of a cognitive problem (Russian National Research Medical University N. I. Pirogov); effects of the availability of information in the cloud storage on the memory of students (Ural State Pedagogical University); interrelation between cognitive development and success in learning Russian in native speakers from Russia, Kyrgyzstan and Moldova (Russian Academy of education). Special attention was paid to the development of professional deformations (V. V. Barabanschikova, A. A. Klimov). Presenters showed that relevant task is to develop new methods for reliable assessment of the severity of professional deformities, for example, using the registration of eye movements. The designed method is sensitive to detect the severity of individual components of the burnout syndrome. Analysis of athletes' eye movements revealed characteristic strategies for responding to components of a stressful situation by avoiding them, which were formed as a response to a high level of experienced professional stress. This is a unique method for assessing 
the causes of professional deformities, including burnout syndrome, as well as their further rehabilitation method.

The section "Interdisciplinary research of the brain: age-related aspect" tried to answer the questions about brain and cognitive development, including self-motion illusion brain mechanisms (Lomonosov Moscow State University), action development in preterm infant (Uppsala, Sweden), identification of early motor signs in infants with neurodevelopmental disorders (Saint-Petersburg State Pediatric Medical University). Special attention was paid to the interdisciplinary aspects in studying the neurocognitive functions (O. A. Lvova). Brain mechanisms of illusion of a person's own body movement (A.I. Kovalev) and motor development (K. Rossander) of premature babies on neurocognitive functions in the context of ontogenesis (early development, childhood period) were discussed. It was also noted that automation of physical activity measurements using technical means is becoming more common in the pediatric environment, for example, the method of evaluating generalized movements of children. The automation speeds up the decision-making stage for a specialist by pre-analyzing markers that characterize spontaneous movements. As a result, instead of a sequential visual method, it is possible to organize an accelerated inspection with maintaining the quality of the analysis.

The section "Chronobiological aspects of psychological well-being and cognitive functions" payed attention to the following research topics: the influence of chronotype on life satisfaction (Perm State University); negative consequences of circadian system dysfunction in schoolchildren and students (Institute of Physiology of Komi Science Centre of the Ural Branch of the Russian Academy of Sciences); the effect of sleep-wake regime in feeding behavior (Institute of Physiology of Komi Science Centre of the Ural Branch of the Russian Academy of Sciences). There was interesting presentation of Social jetlag (SDL) - a mismatch between biological and social clocks. It was shown that SDL has a number of negative consequences for cognitive functions, well-being, and human health. Most often, SDL is observed among school-age children and students, which leads to a decrease in their ability to adapt to the educational process. Individuals with SDL have lower academic performance and lower levels of nonverbal intelligence. Individuals with SDL have a shorter duration, lower quality and efficiency of sleep. They also consume more high-calorie food and are more likely to consume alcohol.

The section "Philosophical and methodological perspectives of cognitive research" was devoted to presentations of the experimental studies that open up new dimensions in the application of techniques due to rethinking of the methodological foundations of psychodiagnostics instruments, including artificial intelligence algorithms, art, and cognitive aspects of emotions: the destructive sides of cognition (Ural Federal University); the influence of modern logic on cognitive methodology (Ural Federal University); the meaning of the complex concept of information for the development of cognitive research (Siberian Federal University). The most important of them were the presentations on the philosophical bases of the cognitive approach. Thus, the talk by professor Bryanik (Ural Federal University) "Alternative methodolo- 
gies as the philosophical basis of cognitive psychology: E. Mach and E. Gusserl" provided an insight into the difference between two methodologies. Ernst Mach believed "energy of the senses" and "energy of consciousness" to be a kind of physical energy, adhering to the psychophysical position of explaining psychological phenomena. The views of E. Mach are opposed to the point of view of E. Husserl, who considers phenomenology as a variety of theory and methodology of psychological sciences. Edmund Husserl considered cognitive processes to be pure phenomena rather than physiological mechanisms. Professor Bryanik focused on the fact that cognitive science nowadays corresponds to the presented alternative of positions: on the one hand, we must consider human cognitive processes as a whole phenomenon, and on the other hand, we must take into account the physiological processes that occur in the human body during cognitive activity. The second report was devoted to the phenomenological-hermeneutic approach of Edmund Husserl, but already within the framework of the basis for cognitive processes. Work was presented by professor Zaitseva from Russian Foreign Trade Academy (Moscow). The author reviews Husserl's concept of "analogizing apperception" and suggests using this term as a description of a fundamental cognitive process. Professor Zaitseva pointed that in her earlier research she tried to show the possibility of describing such procedures as categorization and typing through the concept of analogizing apperception, and also the conceptual similarity of the terms analogizing apperception and the amodal completion procedure. Author showed that the using the concept of Husserl's analogizing apperception will expand the possibilities of phenomenological method in the interdisciplinary cognitive research.

The section "Developmental psychophysiology" covered issues related to different problems in the area of developmental cognitive neuroscience, including parent interaction with toddlers at risk of autism spectrum disorder (Moscow State Psychological and Pedagogical University); multimodal MRI approaches for investigation of the brain white matter development (National Research University Higher School of Economics); an objective assessment of the child's neurocognitive development as a necessary tool for early rehabilitation (Ural State Medical University). Sergey Kiselev and Irina Galasyuk considered the influence of child-parent relations on the child early neurocognitive development. It was shown that the ability of a parent to show verbal responsiveness determines the communicative abilities of children. This idea can explain a correlation between parental responsiveness and the fact that children at risk for ASD often show a low level of initiation of communication, limited opportunities for responses in communication with an adult, and lack or limited amount of eye contact. The role of the neuropsychologist in the development of child-parent interaction in the process of neuropsychological rehabilitation was considered in the talk of Natalia Sadyrova. In the framework of this section, there was the round-table discussion "Parent-child interaction in child neurocognitive development". In these discussions colleagues from Moscow State Psychological and Pedagogical University and the Ural Federal University presented new collaborative research project for investigating 
the influence of parent-child interaction on early child development. The participants discussed first results of these projects.

In the section "Neurocognitive aspects of personality development in late adulthood" presenters covered the following topics: the role of reflexivity in personality development at an elderly age (Saint-Petersburg State University); late-life depressions (Lomonosov Moscow State University); personal mobility in late age (Ural Federal University named after the first President of Russia B.N. Yeltsin). There were discussions of the neurocognitive aspects of human development at a late age (E. L. Soldatova, T. B. Sergeeva), of professionalization (E. F. Zeer) and issues of selective attention in normal cognitive aging (D. V. Tatarinov, B. B. Velichkovsky). It was pointed out that a topical issue of psychological science and practice is the search for personal determinants of human activity in old age, preservation of professional health and psychological well-being. Personal mobility, an integrative quality based on individual properties and manifested in the behavior and activities of the subject, is now being investigated as such determinant. In the study of personal mobility in late adulthood, T. B. Sergeeva identified three study vectors: 1) mobility as an individual property, which is the natural «core» of personal mobility; 2) readiness for mobile behavior; 3 ) mobility as a life strategy.

Young scientists in the different areas of cognitive neuroscience had opportunity to present the results of their researches in the section "Neurotechnology of future". The following reports aroused the great interest: a correlation of diminished working capacity and formal-dynamic properties of individuality; study of the application of virtual reality technologies to learning foreign language; fine motor research in VR.

The II International Forum "Cognitive neuroscience - 2019" contributed to the integration of researches in the field of cognitive neuroscience, pedagogical, developmental psychology, neuropsychology, psychophysiology and medicine. It laid down the foundation for the development of an expert platform in the field of neuroscience at Ural Federal University. Leading experts in the area of cognitive neuroscience discussed the results of their scientific research and outlined new directions for interdisciplinary research. A wide range of researches in the area of cognitive neuroscience was presented. The participants had a good opportunity to see the current level of cognitive neuroscience in Russia and in the world. The Forum created the conditions for development of a new collaborative and cross-cultural research projects and coordinating research protocols.

International Forum on Cognitive Neuroscience in Ekaterinburg is becoming an annual and significant event in the scientific community. The previous Forum "Cognitive neuroscience - 2018" was awarded the Diploma of the nominee of the XX national contest "Golden psyche" in the category "Event of the year in the life of the community".

We invite to participate in the III International Forum "Cognitive neuroscience 2020", which will be held at Ural Federal University, named after the first President of Russia B. N. Yeltsin in Yekaterinburg in November 2020. 


\section{Special circumstances}

The full text of the materials is presented in S. V. Popova \& A. A. Pechenkina (Eds.) (2020). Cognitive Neuroscience - 2019: Materials of the International Forum. Yekaterinburg: UrFU.

The International Forum “Cognitive Neuroscience - 2019” was supported by the Russian Foundation for Basic Research, project \#19-013-20191.

Original manuscript received February 26, 2020 Revised manuscript accepted March 30, 2020

To cite this article: Kiselev, S. Yu., Pavlova, S. V., Kasanov, D. A., Tarasov, D. A., \& Borisov, G. I. (2020). Cognitive neuroscience: Challenge of the time. Lurian Journal, 1 (1), 161-168. DOI: 10.15826/Lurian.2020.1.1.11 